ity to travel someplace warm every winter using research funds. At the predatory conferences I attended in Tokyo, I found it rare for presenters to stay after finishing their own presentations. Exiting with family members carrying guidebooks suggested they had important data collection duties to perform at Tokyo Disneyland.

\section{What Can Be Done?}

There is no magic answer. University faculty, graduate students, and administrators all need more education about the dangers of predatory conferences. Those making an honest mistake and accidently presenting at a predatory conference need to warn colleagues and the wider academic community. Universities need to take greater steps to avoid hosting predatory conferences and to start refusing to hire, promote, or give funding to researchers attending and doing the organizing.

DOI: http://dx.doi.org/ıo.6oI7/ihe.20I8.93.10370

\section{Combating Academic Cor- ruption: Quality Assurance and Accreditation}

\section{JUDITH S. EATON}

Judith S. Eaton is president of the Council for Higher Education Accreditation, US.E-mail:eaton@chea.org.

$\mathrm{W}$ hen the Council for Higher Education Accreditation/ International Quality Group (CHEA/CIQG) issued its Advisory Statement for Effective International Practice: Combatting Corruption and Enhancing Integrity in 20I6, the intent was to focus the attention of the quality assurance and accreditation community on the vital issue of academic corruption. Positioning itself as “... a wake-up call to higher education worldwide-particularly to quality assurance bodies ... in both developing and developed countries ... to challenge and overcome these corrupt practices," the Advisory Statement provides an opportunity to move forward and to engage this important topic.

But deciding how quality assurance and accreditation, our primary means of assuring quality in higher education worldwide, can play a more creative and constructive leadership role in fighting this phenomenon is not easy. Even establishing the boundaries of what we mean is a major challenge. "Academic corruption" in higher education is complex and can include many things, from bribery to fraud to extortion and more, as is clear from examining the
Transparency International definition, turning to various reliable dictionaries, or adopting an operational definition (as done by the Advisory Statement and UNESCO's ETICO, a web-based resource platform targeting the issue of ethics and corruption in education).

\section{Central Issues}

Moving forward, three issues are central to the quality assurance/accreditation community. First, we tend to view fighting corruption through the familiar lens of sustaining academic integrity. It would be useful to address whether tools to enhance academic integrity are the same as tools to fight corruption. Arguably, the tasks are not the same. Second, we may not yet be fully aware of the extent of the role played by corruption in the lives of institutions and programs. Perhaps we need tools to expand this awareness. Third, we need additional means to understand and address the inherent cultural variations in what does and does not count as "corruption" in various countries around the world in order to fight it successfully.

Examining the role of quality assurance/accreditation in addressing corruption primarily through the lens of academic integrity has led to the belief that we are already fighting corruption and there is little more that we need to do. We point to our existing laudable commitment, with quality assurance/accreditation standards and policies that require institutions and programs to demonstrate that they support and take steps to enhance integrity. This includes standards and policies that call for, e.g., honesty in working with students and the public, dedication to the highest of ethical standards in teaching, learning, and research, and full transparency in the conduct of college or university business.

However, are existing standards and policies adequate? Is not fighting corruption more than urging faculty and administrators to affirm academic integrity? Are there practices in place, for example, to make sure that plagiarism does not occur with students or faculty-beyond calling for honesty in assignments, research, and writing, as important as this is? Are steps taken to preclude falsification of transcripts or other credentials using today's technology, going beyond assertions that such practices should not occur? What steps are needed to block the sale of grades or admissions, beyond condemning such practices? The aspirations and exhortations associated with academic integrity are vital, but they are not a substitute for needed action against corruption, as described by the various suggestions in the Advisory Statement.

With regard to increasing the awareness of the importance of addressing corruption, some in the quality assurance/accreditation community, when asked, say that there is no need-corruption has yet to emerge as a significant 
issue for them. They rarely encounter corruption in the course of their examinations and reviews of institutions or programs. Why, in light of the absence of even preliminary evidence of corruption, should they apply their limited resources to address this issue? And in the rare instances in which it is encountered, do not other actors-not quality assurance/accreditation-have primary responsibility here? Corruption, even academic corruption, is an issue for government, for law enforcement, or for the courts.

\section{When it comes to academic corruption, it is not enough to articulate common principles at a general level that we can all embrace and that provide an um- brella for variations in quality assurance practice around the world.}

The challenge here is to acknowledge that, however strong higher education may be in any given country, corruption can and does occur and that we need to act. Are we actually looking for corruption as part of the peer review or self-study process? Is there a set of indicators or triggers that produces greater scrutiny for the presence of corruption? Is there an "anti-corruption" checklist? What are telltale signs that peer reviewers are trained to catch? Yes, this is not the most pleasant of topics, but neither is corruption unearthed by other authorities at the same time that quality assurance/accreditation bodies are asserting that a college or university is meeting its academic integrity expectations.

About cultural variation, what counts as "corruption" differs, sometimes widely, from country to country. Plagiarism, for example, is acceptable in some societies but not others. Nepotism is appropriate within some borders but not others. The selling of degrees or academic credit or college admission is considered corruption in some countries. In others, such practices are viewed as unfortunate but necessary. While quality assurance/accreditation leaders have readily agreed on common practices in many areas-academic leadership role of the university, the importance of scholarship and research, commitment to students throughout higher education-agreement about what counts as corruption is more difficult because of these variations.

\section{How to Move Forward}

When it comes to academic corruption, it is not enough to articulate common principles at a general level that we can all embrace and that provide an umbrella for variations in quality assurance practice around the world. This typi- cal practice in addressing quality assurance issues can certainly help, but we need more. Beyond our attention to academic integrity, we can strengthen anti-corruption practices through additional quality assurance/accreditation standards and policies that focus explicitly on corruption. We need additional training to expand effective scrutiny for the presence of corruption in a college or university as part of ongoing quality review. We can map the variability of what counts or does not count as corruption from country to country. The stakes are exceptionally high with corruption, with enormous potential for harm to students, employers, and the public - and the undermining of the legitimacy of higher education.

Academic corruption is an uncomfortable space for quality assurance. It will take time and a willingness to operate with this discomfort to address these issues more fully as part of establishing a needed leadership role. Moving forward, the suggestions in this article can be part of a successful response to the Advisory Statement wake-up call.

DOI: http://dx.doi.org/ıo.6oI7/ihe.20I8.93.I037I

\section{The Growth of International Student Mobility Is Faltering}

\section{Dirk Van Damme}

Dirk Van Damme is head of division, OECD Directorate for Education and Skills. E-mail: dirk.vandamme@oecd.org.

$\mathrm{O}$ ver the past decades, the numbers of international students have steadily grown. According to data collected by OECD and the UNESCO Institute for Statistics, the total number of internationally mobile students studying in another country than that of their citizenship exploded from I.7 million in I995 to 4.5 million in 20I2. The rationale for this growth is clear. To some extent, international student mobility can be seen as a consequence of global academic inequality. Students are moving to other parts of the globe in order to find the best possible education their money can buy. International student mobility is one of the ways through which the geographical gap between supply and demand is overcome. Investing resources in their children's education in order for them to secure high-quality credentials has become a preferred strategy of affluent middleclass families in emerging countries, especially after their purchasing power started to increase. Some countries were quick to tap into this opportunity and developed strategies to market their higher education offer. International student mobility is one of the most visible ways through which 